\title{
Use of low-cost adsorbent derived from the brazilian cerrado biome to remove pollutants in effluent
}

Uso de adsorvente de baixo custo derivado do bioma cerrado brasileiro para remoção de poluentes em efluentes

Uso de adsorbente de bajo costo derivado del bioma del cerrado brasileño para eliminar contaminantes en efluentes

Received: 09/27/2021 | Reviewed: 10/02/2021 |Accept: 10/03/2021| Published: 10/04/2021

Mateus Rodrigues Brito

ORCID: https://orcid.org/0000-0001-6766-5427

Federal University of Tocantins, Brazil

E-mail: rodriguesmr21@gmail.com

Matheus Gomes Arruda

ORCID: https://orcid.org/0000-0002-5189-0651

Federal Institute of Tocantins, Brazil E-mail: matheusg409@gmail.com

Marcelo Mendes Pedroza

ORCID: https://orcid.org/0000-0001-8886-0053

Federal Institute of Tocantins, Brazil

E-mail: mendes@ifto.edu.br

Helida Monique Cordasso Fagnani

ORCID: https://orcid.org/0000-0002-9249-0603

Federal Institute of Tocantins, Brazil

E-mail: helida.fagnani@ifto.edu.br

Angélica Jaconi

ORCID: https://orcid.org/0000-0002-9917-7767

Federal University of Tocantins, Brazil

E-mail: angelicajaconi@yahoo.com.br

Magale Karine Diel Rambo

ORCID: https://orcid.org/0000-0003-2529-9574

Federal University of Tocantins, Brazil

E-mail: magalerambo@mail.uft.edu.br

\begin{abstract}
The biochar of the Pequi peel represents a sustainable alternative in the process of treating effluents through adsorption system. This study investigates the adsorption capacity in a fixed bed column of the activated biochar from pequi peel (ABPP) to remove the components. The biochar was obtained by pyrolysis, which was activated with zinc Chloride $-\mathrm{ZnCl}_{2}$. Through the Thomas model, it was found that the concentration of Paracetamol of $5 \mathrm{mg} \mathrm{L}^{-1} \mathrm{obtained}$ $3.21 \mathrm{mg} \mathrm{g}^{-1}$ of drug adsorption, which was higher than the adsorption obtained with the concentrations of $10 \mathrm{mg} \mathrm{L}^{-1}$ (3.02 $\mathrm{mg} \mathrm{g}^{-1}$ ) and $20 \mathrm{mg} \mathrm{L}^{1}\left(1.22 \mathrm{mg} \mathrm{g}^{-1}\right)$. Methylene blue was tested with a concentration of $3 \mathrm{mg} \mathrm{L}^{-1}$, adsorbing 8.07 $\mathrm{mg} \mathrm{g}^{-1}$. The data fit the Thomas model with an $\mathrm{R}^{2}$ higher than 0.90 . The capacity of ABPP to adsorb methylene blue and Paracetamol was satisfactory, with adsorbing significant.
\end{abstract}

Keywords: Biomass; Pequi; Biochar; Pollutants.

\section{Resumo}

O biochar da casca do Pequi representa uma alternativa sustentável no processo de tratamento de efluentes por sistema de adsorção. Este estudo investiga a capacidade de adsorção em coluna de leito fixo do biochar ativado da casca do pequi (ABPP) para a remoção dos componentes. O biochar foi obtido por pirólise, que foi ativado com Cloreto de Zinco - $\mathrm{ZnCl}_{2}$. Por meio do modelo de Thomas, constatou-se que a concentração de Paracetamol de $5 \mathrm{mg} \mathrm{L}^{-1}$ obteve $3,21 \mathrm{mg} \mathrm{g}^{-1}$ de adsorção do fármaco, que foi superior à adsorção obtida com as concentrações de $10 \mathrm{mg} \mathrm{L}^{-1}(3,02 \mathrm{mg}$ $\left.\mathrm{g}^{-1}\right)$ e $20 \mathrm{mg} \mathrm{L}^{1}\left(1,22 \mathrm{mg} \mathrm{g}^{-1}\right)$. O azul de metileno foi testado na concentração de $3 \mathrm{mg} \mathrm{L}^{-1}$, adsorvendo $8,07 \mathrm{mg} \mathrm{g}^{-1}$. Os dados se ajustam ao modelo de Thomas com $\mathrm{R}^{2}$ maior que 0,90 . A capacidade do ABPP em adsorver azul de metileno e paracetamol foi satisfatória, com adsorção significativa.

Palavras-chave: Biomassa; Pequi; Biocarvão; Poluentes. 


\section{Resumen}

El biocarbón de cáscara de Pequi representa una alternativa sustentable en el proceso de tratamiento de efluentes mediante sistema de adsorción. Este estudio investiga la capacidad de adsorción en una columna de lecho fijo del biocarbón activado de piel de pequi (ABPP) para eliminar los componentes. El biocarbón se obtuvo por pirólisis, que se activó con Cloruro de zinc - $\mathrm{ZnCl}_{2}$. Através del modelo de Thomas, se encontró que la concentración de Paracetamol de $5 \mathrm{mg} \mathrm{L}^{-1}$ obtuvo $3.21 \mathrm{mg} \mathrm{g}^{-1}$ de adsorción del fármaco, la cual fue superior a la adsorción obtenida con las concentraciones de $10 \mathrm{mg} \mathrm{L}^{-1}\left(3.02 \mathrm{mg} \mathrm{g}^{-1}\right)$. 1) y $20 \mathrm{mg} \mathrm{L1}\left(1,22 \mathrm{mg} \mathrm{g}^{-1}\right)$. Se probó el azul de metileno con una concentración de $3 \mathrm{mg} \mathrm{L}^{-1}$, adsorbiendo $8.07 \mathrm{mg} \mathrm{g}^{-1}$. Los datos se ajustan al modelo de Thomas con un $\mathrm{R}^{2}$ superior a 0,90. La capacidad de ABPP para adsorber azul de metileno y paracetamol fue satisfactoria, con una adsorción significativa.

Palabras clave: Biomasa; Pequi; Biocarbón; Contaminantes.

\section{Introduction}

Over the years, the contamination of water resources through to the inadequate disposal of pollutants has brought global concerns, mainly due to the environmental and public health impacts Cvitanovic \& Hobday, (2018); Moino et al., (2017). Sustainable environmental management has an objective of the United Nations agenda 2030, for reuse of waste to technological innovation and, besides, to the solution of environmental problems Lee et al. (2016).

The high concentration of theses pollutants in wastewater, demonstrated the commonly used on a large scale, showing the growth of the pharmaceutical industry due to the wide accessibility to medicines allied to the offer of medical treatments (Bisognin et al., 2018; Ribas et al., 2021).

Paracetamol (N -acetyl-4-aminophenol), it is an analgesic and antipyretic normally used and can be easily identified in aquatic environments. The order of 58-90\% of the ingested Paracetamol are not metabolized, and are expelled by the human body (Sellaoui et al., 2017). From the point of view of sustainability, the recovery of Paracetamol in wastewater contributes to the recycling of essential non-renewable resources and to the protection of natural water against pollution by drugs (Cao et al., 2020).

Trace levels (ng L-1 to $\mu \mathrm{g} \mathrm{L-1)}$ ) of drugs, has great resistance to biological and physical-chemical degradation (Nascimento et al., 2020), pointing the weakness in the wastewater treatment system (Gurke et al., 2015).

Another pollutant that is identified in effluents is methylene blue (3,7-bis-dimethylaminophenothiazin-5-a chloride), a cationic dye that is used mainly in the textile industry for coloringcotton, paper, hair dyes and others. The wastewater from the process of textile industry has about 8-20\% of dye, with 3-5\% being chemical substances pour out in large quantities in water bodies. The investigation the removal of dye in effluents is essential, due to its strong adsorption on solid supports and toxicity. When the water waste is untreated, the dye interferes with the photosynthetic activity of the aquatic environment and the transparency of the water, inducing changes in water ecosystem (Santos et al., 2021; Jorge et al., 2021; Pin et al., 2021).

The use of activated carbon in the adsorption process is efficient (99.8\%) for removing these pollutants, due to the adsorption power of the biochar where captures and traps the contaminants (Marcelino et al., 2020; Martins et al., 2020).

Biochar are carbon-abundant materials, produced under high and low temperature in the absence of oxygen by the pyrolysis process (Bhuvaneshwari et al., 2019). Renewable biomasses have been widely researched as a raw material for obtaining biochar (Borba et al., 2019; Dong et al., 2020; Gwenzi et al., 2020; Lawal et al., 2021; Pozo et al., 2021; Patra et al., 2021; Olu-Owolabi et al., 2021) and as a filter for pollutants.

In the search for sustainable alternatives, the pequi peel (Caryocar brasilienses) came as an alternative for obtaining activated carbon. However, most of the times the pequi peel are discarded, generating tons of residues (Moura et al., 2013; Borges et al., 2020). Thus, pequi may represent a relevant source of income in the Brazilian cerrado (Basílio et al., 2020; Miranda et al., 2020).

The aim of this study was to investigate the adsorption capacity in a fixed bed column of the activated biochar of 
pequi peel - ABPP to remove methylene blue dye and analgesic Paracetamol in aqueous synthetic solution.

\section{Methodology}

According to Peres et al., (2018) the methodology of this work was quantitative, as numerical data were collected, processed and boosted, generating results. All tests in this study were performed in the laboratory.

\subsection{Biomass Preparation}

The biomass used was fresh pequi peel (Caryocar brasiliense). All residues used in the tests were collected in public areas in Palmas - TO in September/2020. Pequi fruits were pulped and the peels were dried at $60{ }^{\circ} \mathrm{C}$ in an oven for 24 hours in the Innovation and Innovation and use of waste and energy sustainability laboratory (LARSEN) at the Federal Institute of Tocantins, Palmas - TO.

\subsection{Crushing}

In order to obtain homogeneity of the biomass to facilitate the analytical tests, the samples were crushed in a knife milland were sieved $(180-850 \mu \mathrm{m})$ and stored in airtight glass.

\subsection{Briquette Production}

Briquettes were made using fresh biomass, oven dried and milled. Was added $70 \mathrm{ml}$ of distilled water in $300 \mathrm{~g}$ of biomass for hydration occurred for 30 minutes. Then, the hydrated biomass was pressed into a $20 \mathrm{~cm}$ long and $32 \mathrm{~mm}$ diameter pipe. The finished briquettes were dried in an oven at $50{ }^{\circ} \mathrm{C}$ for 24 hours. The productivity of the briquettes was 4 units for each batch.

\subsection{Pyrolysis Process}

Pyrolysis occurred using a tubular fixed-bed quartz reactor, $10 \mathrm{~cm}$ in external diameter and $100 \mathrm{~cm}$ in length. The briquette ( $20 \mathrm{~cm}$ long and $20 \mathrm{~mm}$ in diameter) of the pequi peel was inserted into the reactor in batch mode. Was used water vapor as carrier gas. At the end of the reactor, a condensing system composed of a Friedrich-type condenser, a vacuum flask, two tubes and a $20 \mathrm{~L}$ water tank for cooling the condenser was coupled. With the passage of the vapor it was possible to separate the biogas from the liquid products (bio-oil and acid extract), which are retained in the vacuum flask.

The heating of the reactor was through a reclining oven. To monitor the temperature, a thermocouple was connected to the reactor. The temperature was $500{ }^{\circ} \mathrm{C}$, with a heating rate of $20^{\circ} \mathrm{C}$ and the reaction time was 30 minutes. At the end of the process, the biochar was collected, crushed and sieved $(180-850 \mu \mathrm{m})$.

\subsection{Biochar characterization}

\subsubsection{Approximate chemical analysis, elemental analysis, and calorific value}

Analyses were performed according to the American Society for Tests and Materials (ASTM) procedures, according to ASTM D3173-87 for moisture, ASTM D3174-04 for ash, ASTM D 3175-07 for volatile matter, ASTM D 5373/2008 for elementary analysis $(\mathrm{C}, \mathrm{H}, \mathrm{N})$ and ASTM-D3176-15 for oxygen content $(\mathrm{O})$. From these results, the Higher Heating Value (HHV) was calculated, according to the ASTM-D3176-15 standard. 


\subsubsection{Surface Area Analysis by Brunauer, Emmett and Teller - BET method}

The surface area system and porosimetry (ASAP 2010 micro-merit model) established the N2-BET surface area and the pore size arrangement. The diameter range used as standard was 0.35 to $300 \mathrm{~nm}$ for the pores and 0.01 to $3000 \mathrm{~m}^{2} \mathrm{~g}-1$ in the surface area range, the treatment temperature was 30 to $350{ }^{\circ} \mathrm{C}$.

\subsubsection{Biochar Activation}

The activation process followed the methodology proposed by Costa et al., (2015) The solution was prepared by adding zinc chloride - $\mathrm{ZnCl} 2$ (Merck) with a concentration of $10 \% \mathrm{~m} / \mathrm{v}$, in the proportion 1:5 (m/v). The container with the solution was covered with parafilm for 24 hours. Then, the samples were washed with distilled water and dried in an oven at $110 \pm 5{ }^{\circ} \mathrm{C}$ for 12 hours.

The dry biochar was inserted in a cordierite crucible, closed with rockwool and cordierite plate, and again taken to the muffle to be pyrolyzed at $600 \pm 5^{\circ} \mathrm{C}$, for 2 hours. Subsequently, the hydrochloric acid solution - $\mathrm{HCl}$ (Merck), at 2 mol L-1 was used to remove and unclog the pores. To finish the process, the biochar was again dried in an oven at $110 \pm 5{ }^{\circ} \mathrm{C}$ for 24 hours, thus obtaining the ABPP.

\subsection{Adsorption Tests}

In this study, two adsorption systems were carried out: testing the adsorption of methylene blue dye and of Paracetamol and adding two grams of activated biochar.

\subsection{Fixed bed column adsorption}

The fixed bed column adsorption system consists of the circulation of the effluent to be treated, where the effluent control of the concentration is performed to determine the breakthrough curve (Ortiz et al., 2019).

The fixed bed adsorption study in this work was carried out in a system consisting of a tank containing the solution with the pollutants (Methylene blue and Paracetamol), a peristaltic pump for the flow control, a column with effluent with the pollutants and a filter coupled to this column containing the ABPP. The effluent contained in the tank was taken to the fixed bed column by the pump. In the column, the effluent was treated in a downward flow using a filter with biochar, and the flow control of the effluent that passed through the filter was done manually by a tap.

\subsection{Methylene blue adsorption}

The adsorption of the effluent was carried out in a downward filter, using ABPP. The continuous flow test was carried out, and the dye solution contained a concentration of $3 \mathrm{mg} \mathrm{L-1}$ and $\mathrm{pH}$ 6.6.

The filtration system consisted of: lower tank of $50 \mathrm{~L}$, upper tank of $10 \mathrm{~L}$ with drain system and filter systems in series of sand and biochar. The dye was transported to the upper tank using a submerged pump attached to the lower tank. To maintain the volume of the liquid and minimize variations in the flow of the liquid during filtration, a drain system was used.

The transport of liquids in the upper tank was carried out by three pipes: feeding from the lower tank, drain to the lower tank and filter feeding, it was done by gravity. The dimensions of the filters were: total height of the pipe $40 \mathrm{~cm}$, height of the biochar and sand in the pipe, $11 \mathrm{~cm}$, diameter of the pipe $2.0 \mathrm{~cm}$. In each batch of tests, about $3 \mathrm{~g}$ of ABPP was inserted into the filter.

Using a double-beam spectrophotometer (PERKIN ELMER, LAMBADA 750), the adsorption of the dye was 
measured at a wavelength of $660 \mathrm{~nm}$, with calibration curve (Silva et al., 2017).

\subsection{Adsorption of Paracetamol}

The Paracetamol test was performed on a fixed bed column, with continuous flow, using the pollutant solution in concentrations of 5, 10 and $20 \mathrm{mg} \mathrm{L-1}$ with the following values of $\mathrm{pH} \mathrm{7.2,7.4} \mathrm{and} \mathrm{7.1} \mathrm{respectively.} \mathrm{The} \mathrm{filtration} \mathrm{system}$ consists of a tank of $10 \mathrm{~L}$ in volume and $1 \mathrm{~m}$ in height, containing a biochar filter and sand, using 3 grams of ABPP. The filter was filled up by gravity.

The pollutant adsorption was measured using a spectrophotometer (DR6000 UV/VIS), at wavelength of $250 \mathrm{~nm}$, with a calibration curve.

\subsection{Adsorption isotherms}

\subsubsection{Thomas model}

The Thomas model (Thomas, 1944) is applied to express the performance of the adsorption process in a fixed bed column, being indicated fo favorable and/or unfavorable conditions of adsorption. It is common to apply this model to determine the maximum adsorption capacity of the adsorbent in continuous systems. With the Thomas model (Eq. 1) it is possible to determine the adsorption (Nascimento et al., 2020). Where takes into account the physical properties of the adsorbent and adsorbate, in addition, the temperature and pressure of the systems must be constant and the external resistance to mass transfer and axial and radical dispersion are considered negligible in the column (Moino et al., 2017).

$$
\frac{c}{C 0}=\frac{1}{1+\exp \left(\frac{K t h\left[Q t^{h} * m s-C_{0} V \theta\right)}{F m}\right)}
$$

Where:

$\mathrm{C}$ : concentration of the pollutant in a given volume (mg L-1 $\left.{ }^{1}\right)$;

$\mathrm{C} 0$ : initial concentration of the solution $\left(\mathrm{mg} \mathrm{L}^{-1}\right)$;

Kth: Thomas constant;

Qth: maximum adsorption capacity $\left(\mathrm{mg} \mathrm{g}^{-1}\right)$;

ms: mass of adsorbent in grams $(\mathrm{g})$;

Fm: volumetric flow in $\left(\mathrm{L} \mathrm{min}^{-1}\right)$;

Ve: volume effluent to the column (mL).

For the work tests, Thomas's formula was linearized. The data were expressed in: ln of C0/C versus volume (V). Thus, equation 1 is transformed into Eq. 2. 
$\ln \left(\begin{array}{c}C 0 \\ C-1\end{array}\right)=\frac{K t h * Q t h * m s}{F_{m}}-\frac{K t h * C 0 * V e}{F_{m}}$

\section{Results and Discussion}

\subsection{Characterization of biochar from pequi peel}

In our previous studies, Brito et al., (2020), the activated biochar of the pequi peel was characterized and the results are shown in Table 1.

Table 1 - Characterization of biochar from pequi peel

\begin{tabular}{cc}
\hline Analysis (\%) & Activated Biochar \\
\hline Moisture & $6.24 \pm 0.001$ \\
Ashe & $9.01 \pm 0.001$ \\
VM & $46.66 \pm 1.340$ \\
FC & $38.09 \pm 0.001$ \\
pH & $4.71 \pm 0.001$ \\
C & $78.74 \pm 0.226$ \\
H & $2.63 \pm 0.128$ \\
N & $1.66 \pm 0.029$ \\
O & $7.72 \pm 0.019$ \\
S & $0.25 \pm 0.668$ \\
HHV $\left(\mathrm{kJ} . \mathrm{g}^{-1}\right)$ & $29.59 \pm 0.045$ \\
BET surface area $\left(\mathrm{m}^{2} / \mathrm{g}\right)$ & $30.30 \pm 0.304$ \\
Langmuir surface area $\left(\mathrm{m}^{2} \mathrm{~g}^{-1}\right)$ & $39.11 \pm 0.364$ \\
Size micropores $\left(\mathrm{cm}^{3} \mathrm{~g}^{-1}\right)$ & $0.023 \pm 0.001$
\end{tabular}

MV: Volatile matter ; FC: Fixed carbon; pH: Potential hydrogen; C: Carbon; H: Hydrogen; N: Nitrogen; O: Oxygen; S: Sulfur; HHV: Higher heating value. Fonte: Brito et al., 2020.

Source: Authors (2021).

Through Table 1, we can observe the characterization of the Pequi bark. One of the axes of this research is the production of biochar, and we must consider: Fixed carbon, Carbon, Higher heating value, BET surface area $\left(\mathrm{m}^{2} / \mathrm{g}\right)$ and Size micropores $\left(\mathrm{cm}^{3} \mathrm{~g}-1\right)$ which demonstrate the quality of the biochar.

The low moisture content found was a satisfactory result for the adsorption process. Since high moisture content influences on the quality of the biochar and consequently on application as an adsorbent, reducing the efficiency of pyrolysis and decomposing oxygenated compounds. Furthermore, the moisture ratio is inversely proportional to HHV, the lower the moisture the better the HHV and the greater the adsorption capacity of the biochar (Pedroza et al., 2014). 
In the adsorption system, the $\mathrm{pH}$ interferes with the distribution of chemical species and electrical loads. The $\mathrm{pH}$ effect determines how surface charges of the adsorbent interact with the treated effluent solution. It is important to know that, the $\mathrm{pH}$ value depends on the composition and surface characteristics of the biomass, depending on the $\mathrm{pH}$ range, where the electrical loads on the surface of the adsorbent are zero, the so-called zero electrical load point (Oliveira et al., 2020). The acid $\mathrm{pH}$ of ABPP is 4.71 when interacting with the heated solutions of the pollutants methylene blue (3 - $6.6 \mathrm{mg}$ L-1) and Paracetamol (5 - 7.2 mg L-1; 10 - $7.4 \mathrm{mg} \mathrm{L-1}$; and 20 - $7.1 \mathrm{mg} \mathrm{L}-1$ ) which have a neutral features, increase the adsorption process, as the attraction of negative charges present in ABPP and positive charges in aqueous solutions contribute to the attraction process between adsorbent and adsorbate.

The biomass fraction does not have volatile material, called fixed carbon, is the most resistant fraction that remains in the biochar after the pyrolytic process (Veiga et al., 2017). The low $\mathrm{H} / \mathrm{C}$ and $\mathrm{O} / \mathrm{C}$ ratios demonstrate the presence of aromatic structures and carbon stability, contributing to better adsorbent efficiency (Gascó et al., 2018).

The surface area and pore volume are relevant characteristics in the adsorption process. As they are involved in the transport of molecules and nutrients, if the surface area are larger, greater the material's ability to adsorb pollutants. On the other hand, micropores, increase the hydrodynamics and aeration of the adsorbent/pollutant ratio (Ferraro et al., 2021).

\subsection{The breakthrough curves of Methylene Blue and Paracetamol}

To demonstrate the behavior of the pollutant, breakthrough curve tests were performed (Figure 1.).

Figure 1 - Pollutant rupture curve: (a) Methylene Blue with a concentration of $3 \mathrm{mg} \mathrm{L}^{-1}$, (b) Paracetamol with a concentration of $5 \mathrm{mg} \mathrm{L}^{-1}$, (c) Paracetamol with a concentration of $10 \mathrm{mg} \mathrm{L}^{-1}$ and (d) Paracetamol with a concentration $20 \mathrm{mg} \mathrm{L}^{-1}$
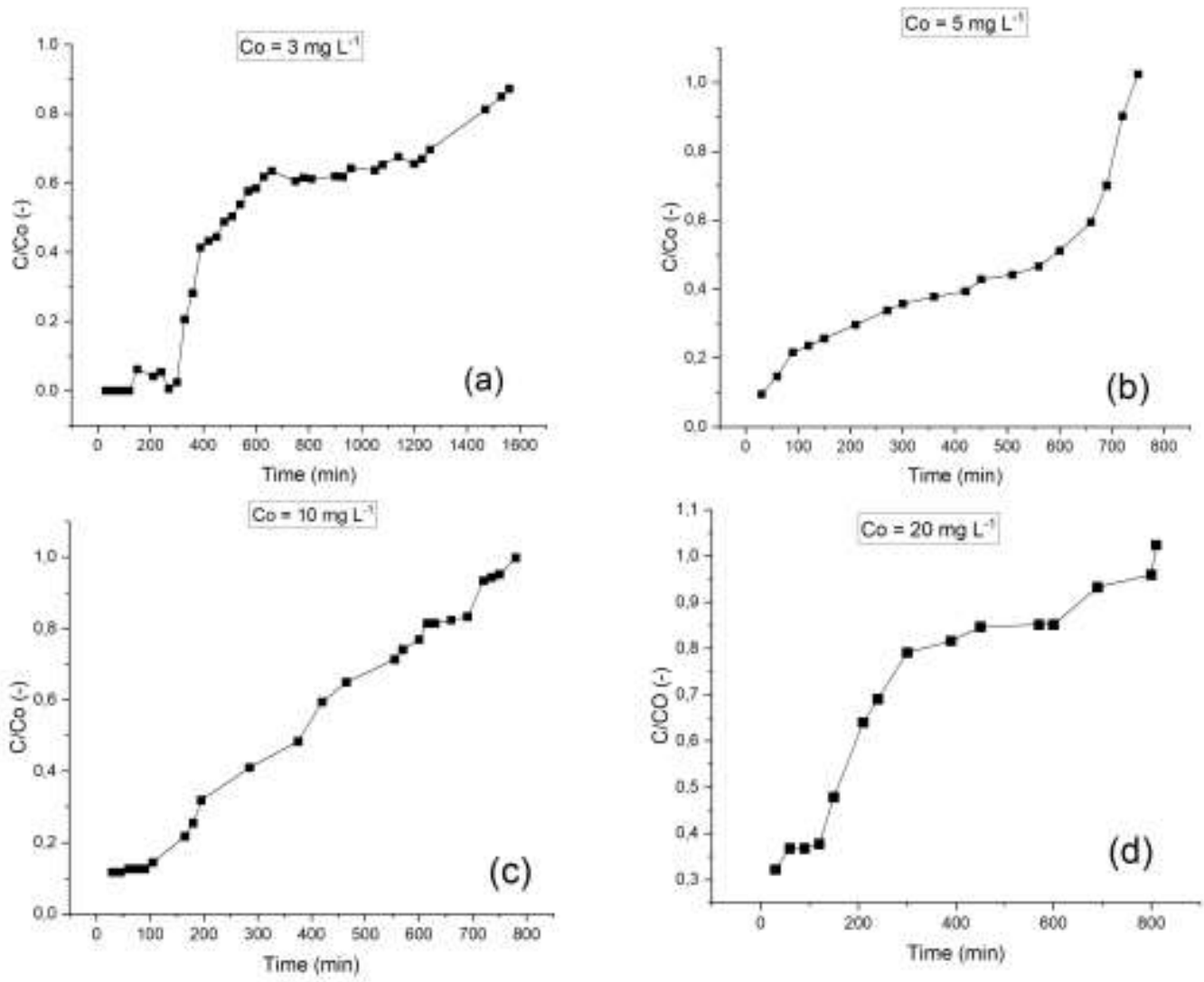

Source: Authors (2021). 
The curupture curve demonstrates the relationship of final concentration (C) and concentration $(\mathrm{C} 0)$ with respect to time. The so-called breakdown occurs when the $\mathrm{C} / \mathrm{C} 0$ ratio reaches 1 , the longer it takes, the better the efficiency of the coal in removing pollutants.

Regarding the breakthrough curve, it is important to note that it demonstrates how the movement of the transfer mass occurs in the bed, so the breakthrough time is the time for the concentration of the effluent to reach $10 \%$ of the initial concentration. [(Gabelman A, 2017)]. According to Figure 1a, the increase in the $\mathrm{C} / \mathrm{C} 0$ concentration of methylene blue, shows the time decreases. That the breakthrough time is faster as the concentration is high. This phenomenon occurs because it has more adsorbate available in the solution when the concentration is higher, saturating the pores of the adsorbents in a shorter time. This same behavior was portrayed by Andrade et al., (2017) who investigated the breakthrough curves of the adsorption system with coconut endocarp biochar to remove methylene blue.

The breakthrough curves obtained show a sigmoidal type profile (S-shaped), justified by the low concentration of the treated effluent of Paracetamol. Afterwards the elevation of the output concentration of Paracetamol increases suddenly, called the break point. When the input value of the effluent is close to the output value of the effluent, then the biochar has reached the saturation point. This same performance was observed by Rodrigues et al., (2019) when researching the removal of caffeine in a fixed bed column. The equilibrium/saturation ratio point is when the output concentration reached $95 \%$ of the initial concentration.

In relation to the increase in concentration from $5 \mathrm{mg} \mathrm{L}^{-1}$ (Figure 1b) to $20 \mathrm{mg} \mathrm{L}^{-1}$ (Figure 1d) of Paracetamol, the solution saturation time increased, demonstrating that high concentrations of pollutant results to increase of transfer mass resistance. The adsorbent saturates slowly, causing an increase in the saturation time. Haro et al., (2021) demonstrated the removal of Paracetamol by adsorption in activated biochar, and identified the same behavior regarding the saturation time, the higher the concentration of the pollutant, the greater the saturation time.

Regarding the equilibrium time, results of this research $750 \mathrm{~min}\left(5 \mathrm{mg} \mathrm{L}^{-1}\right), 720\left(10 \mathrm{mg} \mathrm{L}^{-1}\right), 810 \mathrm{~min}\left(20 \mathrm{mg} \mathrm{L}^{-1}\right)$, were superior to some studies (Nourmoradi et al., 2018; Lawal et al., 2021), demonstrating that it can be a good aspect, since the longer it takes the biochar to reach the equilibrium point, the longer it will be adsorbing, due to the removal of the pollutant.

\subsection{Biochar's efficiency in removing pollutants}

Figure 2 demonstrates the efficiency to remove methylene blue and Paracetamol according to their initial concentration as a function of the flow and the operating time of the system. The operation of the adsorption system was 26 hours for methylene blue (Figure 2 a) and the average hour was 12.5 hours for Paracetamol. 
Figure 2 - Biochar removal efficiency: (a) methylene blue with a concentration of $3 \mathrm{mg} \mathrm{L}^{-1}$, (b) Paracetamol with a concentration of $5 \mathrm{mg} \mathrm{L}^{-1}$, (c) Paracetamol with a concentration of $10 \mathrm{mg} \mathrm{L}^{-1}$ and (d) Paracetamol with a concentration $20 \mathrm{mg}$ $\mathrm{L}^{-1}$.
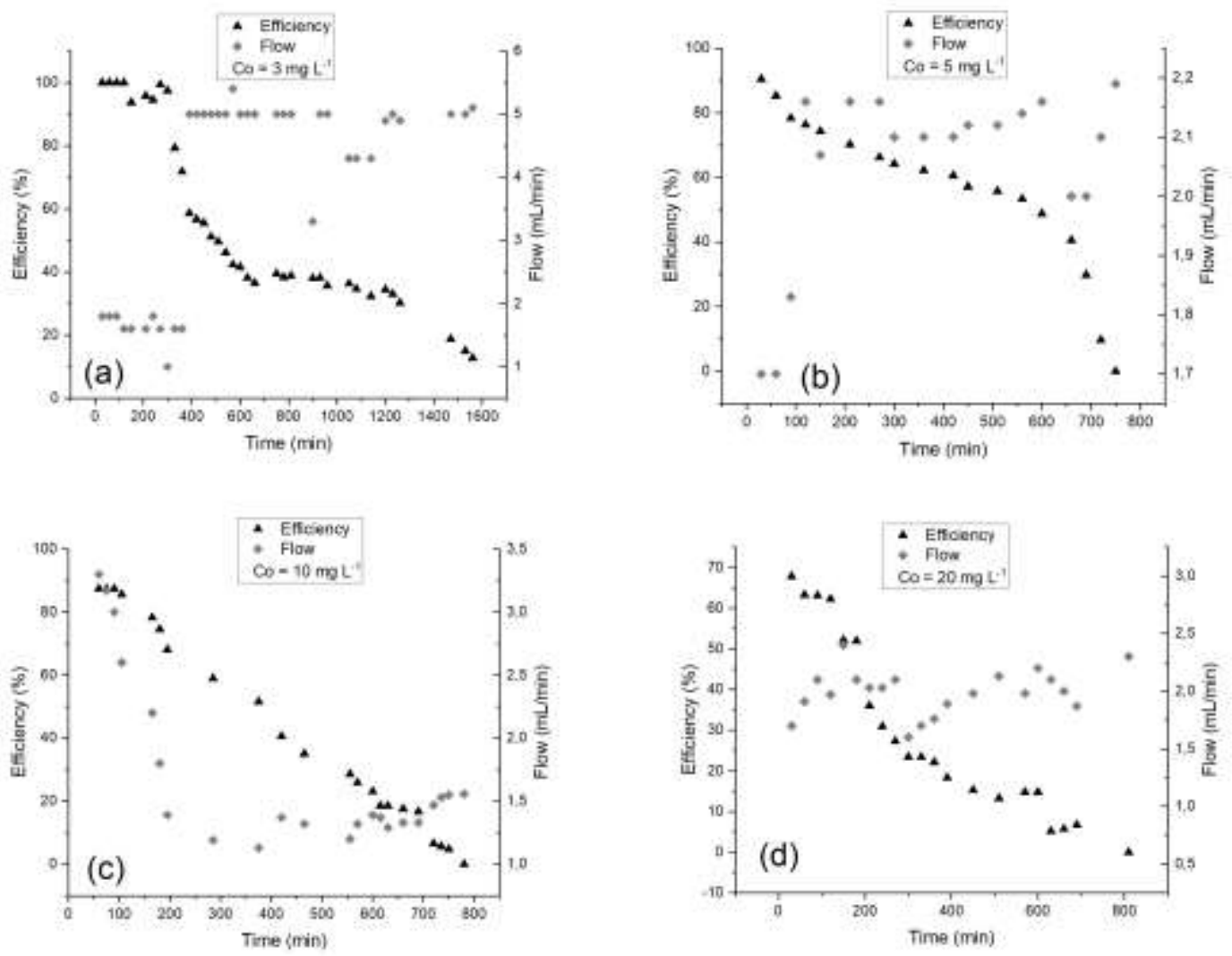

Source: Authors (2021).

Biochar efficiency is related to the time it takes to saturate. Thus, the longer the biochar is operating with high removal rates, the more efficient it will be in removing pollutants.

In the first 3.3 hours of operation, at average flow rate of $1.7 \mathrm{~mL} \mathrm{~min}^{-1}$, the filter achieved $100 \%$ detention. Then the flow rate was increased and maintained at $5 \mathrm{~mL} \mathrm{~min}^{-1}$, in this phase there was a decay of efficiency due to the saturation of the biochar. The lowest rate of removal from the system was $12.5 \%$ with 26 hours of operation.

The Paracetamol adsorption system operated at different times depending on the concentration of the solution. The operation of the $5 \mathrm{mg} \mathrm{L}^{-1}$ system (Figure $2 \mathrm{~b}$ ) operated for 12.5 hours, the system with $10 \mathrm{mg} \mathrm{L}^{-1}$ (Figure $2 \mathrm{c}$ ) operated for 13 hours and the system with $20 \mathrm{mg} \mathrm{L}^{-1}$ (Figure $2 \mathrm{~d}$ ) operated for 7.5 hours. The average flow and the concentration of the filtered effluent were measured every 30 minutes.

Regarding the system with effluent of $5 \mathrm{mg} \mathrm{L}^{-1}$, the filter showed $90 \%$ detention in the first $30 \mathrm{~min}$ of operation. The detention remained above $70 \%$ with an average flow rate of $2 \mathrm{~mL} \mathrm{~min}^{-1}$. After 8.5 hours of operation, the decay of efficiency was $55 \%$, occurs constantly due to the proximity of the saturation of the biochar. In this batch, the lowest efficiency was $9 \%$ at 12 hours with an average flow rate of $2 \mathrm{~mL} \mathrm{~min}^{-1}$.

In the $10 \mathrm{mg} \mathrm{L}^{-1}$ system, the best detention was $88 \%$, which was maintained in the first 100 min of operation with an average flow rate of $1.4 \mathrm{~mL} \mathrm{~min}^{-1}$. Then the detention decreases constantly, up to $4.8 \%$ less than that of 12.5 hours of operation with an average flow rate of $1.4 \mathrm{~mL} \mathrm{~min}^{-1}$. 
During the operation of the system with a concentration of $20 \mathrm{mg} \mathrm{L}^{-1}$, the maximum detection of $67.8 \%$ was less than the filters tested previously. The average flow rate $2.2 \mathrm{~mL} \mathrm{~min}^{-1}$ of this system was higher than the others, reducing the removal efficiency. A detention rate greater than $60 \%$ was constant during the first 120 min of operation of the system, then the removal decreased, reaching $2.17 \%$ at 7 hours, with an average flow rate of $2.2 \mathrm{~mL} \mathrm{~min}^{-1}$. Rodrigues et al., (2019), when researching the efficiency of the green coconut endocarp biochar in removing caffeine in a system with $30 \mathrm{mg} \mathrm{L}^{-1}$, obtained only $17 \%$ of efficiency, that is, detention lower than those identified in this research.

In their study of adsorption of Paracetamol with commercial activated biochar, Haro et al., (2021), obtained 95\% removal for $120 \mathrm{~min}$ with a concentration of $5 \mathrm{~g} \mathrm{~L}^{-1}$, a result close to that obtained in the present study. In their investigation on the potential of adsorption of the grape stalk biochar on Paracetamol (20 mg L-1 ), Villaescusa et al., (2011) obtained a removal of $30 \%$, a percentage lower than that identified in this work when comparing the concentration of the pollutant.

The best detention occurred in the system with the lower concentration of $5 \mathrm{mg} \mathrm{L}^{-1}$ with $90 \%$ removal efficiency, a similar result to that found by Gupta and Nain (2019). This occurs because of the solute-adsorbent interactions, which at lower concentrations are stronger than the higher concentrations. This behavior is observed in discontinuous systems due to the balance between the adsorbate retained in the adsorbent and the solute in solution (Nascimento et al., 2020).

\subsection{Adsorption rate of biochar}

The literature (Table 2) is a tricky point, due to the variables chosen both for the synthesis of materials and for the removal tests, which differ from one study to another.

Table 2 Comparison of the adsorption capacity of the biochar of this study with the literature.

\begin{tabular}{lcccc}
\hline Biochar & C (mg $\left.\mathbf{~ L ~}^{\mathbf{1}}\right)$ & Pollutant & AC $\left(\mathbf{m g ~ g}^{-\mathbf{1}}\right)$ & Reference \\
\hline ABPP & 3 & $(2)$ & 4.77 & This study \\
ABPP & 5 & $(1)$ & 3.08 & This study \\
ABPP & 10 & $(1)$ & 3.03 & This study \\
ABPP & 20 & $(1)$ & 2.81 & This study \\
CM & 5 & $(1)$ & 3.6 & Haro et al., (2021) \\
PE & 20 & $(1)$ & 90 & Fuentes et al., (2020) \\
PE & 10 & $(1)$ & 70 & Fuentes et al., (2020) \\
PP & 10 & $(2)$ & 1.28 & Resplandes (2021) \\
PP & 10 & $(2)$ & 1.17 & Resplandes (2021) \\
TB & 3 & $(2)$ & 1.2 & Lima et al., (2018) \\
TB & 5 & $(1)$ & 1.3 & Lima et al., (2018) \\
CS & 40 & & 2.84 & Yanyan (2018) \\
\hline
\end{tabular}

(1): Paracetamol; (2): Methylene blue.

C: Pollutant concentration; AC: Adsorption capacity; ABPP: Activated biochar of pequi peel; CM: Commercial biochar; PE: Eucalyptus pruning; PP: Pineapple peel; TB: timbaúva bark; CS: Coco shell.

Source: Authors (2021). 
Table 2 shows a comparison of the adsorption capacity of the biochar of this study with the literature. Other biochars from similar biomasses are compared to the results of this research.

Table 2 presents data from the literature on adsorption of methylene blue and paracetamol in different biomasses and concentrations. It is possible to see that the ABPP obtained high adsorption compared to the other authors. Lima et al., (2018) investigated the application of Timbaúvas bark biochar to adsorb methylene blue using a concentration of $3 \mathrm{mg} \mathrm{\textrm {L } ^ { - 1 }}$ and obtained an adsorption $\left(1.2 \mathrm{mg} \mathrm{g}^{-1}\right)$ lower than this study $\left(4.77 \mathrm{mg} \mathrm{g}^{-1}\right)$. The Peel Pineapple and Timbaúva Bark biochar obtained lower adsorption values at higher concentrations of methylene blue than the used in this study.

It is important to highlight that Paracetamol has high hydrophilicity, which hinders its retention with the adsorbent Ferchichi \& Dhaouadi (2016), demonstrating that it is not easily removed by the tested biochar. The adsorption capacity of Pineapple peel in the case of Paracetamol is close to the literature. The best condition obtained in this research was with a concentration of $5 \mathrm{mg} \mathrm{L}^{-1}$, adsorbing $3.08 \mathrm{mg} \mathrm{g}^{-1}$. Some works, García-Mateos et al., (2015), Ferreira et al., (2018), Lima et al., (2019), demonstrated higher adsorption rates when compared to the present study. The molecular structure of Paracetamol $\left(\mathrm{C}_{8} \mathrm{H}_{9} \mathrm{NO}_{2}\right)$ has an aromatic ring and double bonds; if the drug is not well diluted and well homogenized, there is the possibility of electrostatic attraction between the double bond $\mathrm{O}$ and $\mathrm{OH}$, which may form Paracetamol agglomerate, which will increase the size of the molecule, making it difficult for the biochar to adsorbate.

Nascimento et al., (2020) said that high concentrations of solute affect the efficiency of removal of the pollutant by biochar.

Another characteristic in this study is the low content of adsorption of $2.81 \mathrm{mg} \mathrm{g}^{-1}$ in the concentration of $20 \mathrm{mg} \mathrm{L}$. This low removal of Paracetamol when compared to the other concentrations can be justified by the preferential routes taken by the pollutant in the filter during the adsorption process. This means that the effluent was probably treated by only one region of the filter, limiting its potential for adsorption of ABPP (Nascimento et al., 2020).

The direction of the fixed bed column in which the adsorption tests were carried out in this study was downward, this contributed to the establish the preferential paths. The operation of the column in a fixed bed, when carried out in a downward flow, can cause the compactation of the bed, resulting to system loss and the creating preferential paths, reducing the efficiency of the biochar in the treatment of the effluent from the adsorption process (Schmal M, 2014).

\subsection{Thomas Model}

The Thomas model assumes that in the fixed bed adsorption system the flow is continuous, and the adsorption follows the Langmuir isotherm, disregarding the radial and/or axial dispersion and admits second order reversible kinetics (Thomas HC, 1944). 
Figure 3 - Modeling the data according to the Thomas model: (a) methylene blue with a concentration of 3 mg $\mathrm{L}^{-1}$, (b) Paracetamol with a concentration of $5 \mathrm{mg} \mathrm{L}^{-1}$, (c) Paracetamol with a concentration of $10 \mathrm{mg} \mathrm{L}^{-1}$ and (d) Paracetamol with a concentration of $20 \mathrm{mg} \mathrm{L}^{-1}$.
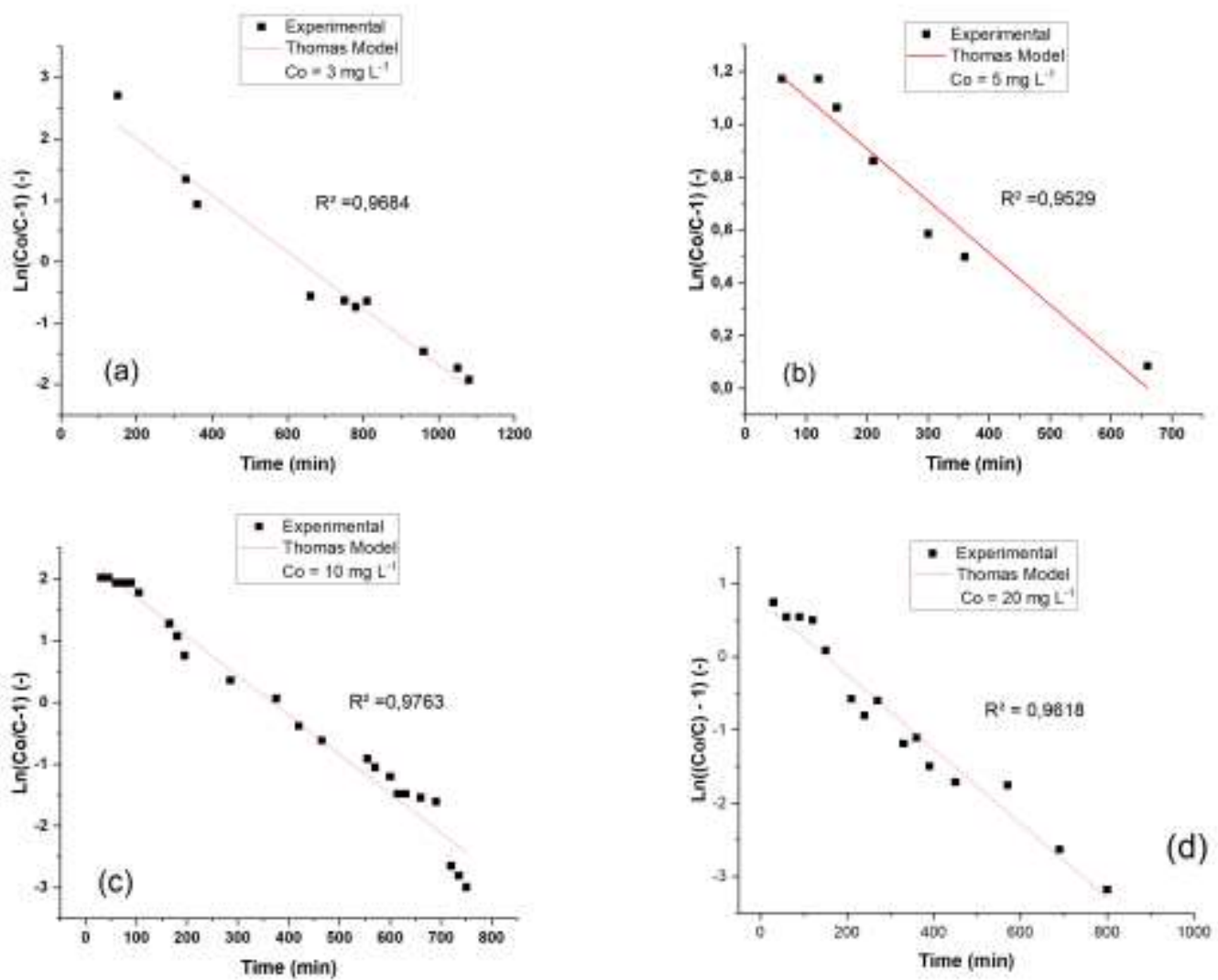

Source: Authors (2021).

Thomas' model demonstrates how the data from adsorption systems fit the model. The closer to 1 the value of $\mathrm{R}^{2}$, the better the fit of the data.

The determination coefficient $\left(\mathrm{R}^{2}\right)$ was used as a parameter to verify which of the concentrations best adapted to the Thomas model (Figure3). According to Nascimento et al., (2020) the $\mathrm{R}^{2}$ is the most used parameter to identify the efficiency of the adjustment of the theoretical model referring to the data system (adsorption system). Concentrations of $10 \mathrm{and}^{20} \mathrm{mgL}^{-1} \mathrm{of}$ Paracetamol obtained $\mathrm{R}^{2}$ closer to 1 , that is to say that the data of these systems adapted to the Thomas Model more efficiently than the others. Franco et al., (2018), when studying the use of commercial biochar for the removal of Paracetamol, using the Thomas model, obtained $\mathrm{R}^{2}$ of 0.83 , a value well below that obtained in this research.

Figure 3 shows the Thomas model. Figures $3 \mathrm{c}$ and $3 \mathrm{~d}$ shows the adsorption systems that best adapted the modelling of the Thomas model, being higher $\mathrm{R}^{2}$ values than the other concentrations.

\section{Conclusion}

Activated biochar of pequi peel was applied in a fixed bed adsorption system, in two pollutants that establish largescale impacts on the environment, mainly in water bodies. Regarding Paracetamol, the effluent tested at a concentration of 5 $\mathrm{mg} \mathrm{L}^{-1}$ obtained $90 \%$ removal of the drug and $3.08 \mathrm{mg} \mathrm{g}^{-1}$ of adsorption, presenting itself as the best option. Regarding methylene blue, $100 \%$ dye removal and $4.47 \mathrm{mg} \mathrm{g}^{-1}$ of adsorption were obtained. The $\mathrm{R}^{2}$ values in all systems were greater 
than 0.95 , demonstration the efficiency of the data modelling (Thomas model), the 10 and $20 \mathrm{mg} \mathrm{L}^{-1}$ solutions of Paracetamol were the ones that presented the best fit for the model.

The use of this biomass prevents the waste from being inadequate discarded resulting environmental impacts. The utilization through the biochar managed to adsorb significant amounts of drug and dye present in the water.

The possibility of applying pequi peel, in segments of effluent treatment and biorefinery, has great potential for economic return to extractivists. In future research, research on acidic substances in the biochar activation process can be verified in order to improve the efficiency of pollutant removal. In addition to Methylene Blue and Paracetamol, other drugs from the group of antibiotics and analgesics can be verified in the biochar adsorption process from this biomass

\section{Acknowledgments}

The authors are grateful to the Coordination for the Improvement of Higher Education Personnel for the scholarship granted (CAPES), the Graduate Support Program for all financial support and the Federal University of Tocantins, for the PPGCiamb (Graduate Program in Environmental Sciences) for the support in publication, and the Federal Institute of Science and Technology of Tocantins for all the support and for allowing the use of the laboratories.

\section{References}

American Society for Testing and Materials - ASTM International. ASTM D 3173-87 (2003). Standard method for determination of moisture content in biomass.

American Society for Testing and Materials - ASTM International. ASTM D 3174-04 (2004). Standard method for ash in the analysis sample of coal and coke.

American Society for Testing and Materials - ASTM International. ASTM D 3175-07 (2007). Standard method for volatile matter in the analysis sample of coal.

American Society for Testing and Materials - ASTM International. ASTM D 1762 - 84 (2013). Standard Test Method for Chemical Analysis of Wood.

American Society for Testing and Materials - ASTM International. ASTM D3176 - 15. Standard Practice for Ultimate Analysis of Coal and Coke.

Andrade, R. G. S. A., Andrade, K. R. B., Melo, F. D. S., Barbosa, J. I., Soletti, S. H. V., \& Carvalho (2017) Obtenção de curvas de ruptura na adsorção do Azul de Metileno em carvão ativado do endocarpo do coco. Blucher Chemical Engineering Proceedings. doi:10.1016/chemeng-cobeqic2017-290.

Basílio, J. J. N., Rodrigues L. A., Silva, M. S. A., Colen F., \& Oliveira, L. S. (2020) Pequi bark biochar as a substrate component for the production of Eucalyptus urophylla S. T. seedlings. Agricultural Sciences Notebook. doi:10.35699/2447-6218.2020.24836.

Bhuvaneshwari, H., Hettiarachchi, J. N., \& Meegoda (2019) Crop residue burning in India: policy challenges and potential solutions. Int. J. Environ. Res. and Public Health. doi:10.3390/ijerph16050832.

Bisognin, R. P., Wolff, D. B., \& Carissimi, E. ;(2018) Review of pharmaceuticals in the environment. Revista DAE. doi:10.4322/dae.2018.009.

Borba, L. L., Cuba, R. M. F., Terán, F. J. C., Castro, M. N., \& Mendes, T. A. (2019) Use of Adsorbent Biochar from Pequi (Caryocar Brasiliense) Husks for the Removal of Commercial Formulation of Glyphosate from Aqueous Media. Brazilian Archives of Biology and Technology. doi: 10.1590/1678-43242019180450 .

Borges, M. S., Barbosa, R. S., Rambo, M. K., Rambo, M. C., \& Scapin, E. (2020) Evaluation of residual biomass produced in Cerrado Tocantinense as potential raw biomass for biorefinery. Biomass Conversion and Biorefinery. doi:10.1007/s13399-020-00892.

Brito, M. R., Junior, C. C. S., Rambo, M. K. D., Scapin, E., Pedroza, M. M., Rambo, M. C. D., \& Barbosa, L. N. (2020) Utilization of pequi Residual Biomass from the Brazilian cerrado for obtaining raw and activated biochars and bio-oil. International. Journal of Advanced Engineering Research and Science 7:1-9. doi:7. 251-259. 10.22161/ijaers.79.29.

Cao, H., Wu, X., Syed-Hassan, S. S. A., Zhang, S., Mood, S. H., Milan, Y. J., \& Garcia-Perez, M. (2020) Characteristics and mechanisms of phosphorous adsorption by rape straw-derived biochar functionalized with calcium from eggshell. Bioresource Technology. doi:10.1016/j.biortech.2020.124063.

CERNE. doi:10.1590/01047760201723042373.

Costa, P. D., Furmanski, L. M., \& Dominguini, L. (2015) Produção, caracterização e aplicação de carvão ativado de casca de nozes para adsorção de azul de metileno. Revista virtual de química 7:1272-1285. doi:10.5935/1984-6835.20150070.

Cvitanovic, C., \& Hobday, A. (2018) Building optimism at the environmental science-policy-practice interface through the study of bright spots. Nature communications. doi:10.1038/s41467-018-05977-w. 
Dong, T. N., Hai, N. T., Ruey-Shin, J. et al (2020) Adsorption process and mechanism of acetaminophen onto commercial activated carbon. Journal of Environmental Chemical Engineering 8:104-408. doi: 10.1016/j.jece.2020.104408.

Ferchichi, M., \& Dhaouadi, H. (2016) Sorption of paracetamol onto biomaterials. Water Sci Technol. doi: 10.2166/wst.2016.218.

Ferraro, G., Pecori, G., Rosi, L. et al. (2021) Biochar da pirólise em escala de laboratório: influência da matéria-prima e da temperatura operacional. Biomass Conv. Bioref. doi:10.1007/s13399-021-01303-5.

Ferreira, R. C. et al. (2018) Use of fresh palm oil activated charcoal and acid-functionalized in the adsorption of paracetamol. Matter. doi: 10.1590/s1517707620170001.0304.

Franco, M. A. E., Carvalho CB, Bonetto MM, Pelegrini SR, \& Féris L A (2018) Diclofenac removal from water by adsorption using activated carbon in batch mode and fixed-bed column: isotherms, thermodynamic study and breakthrough curves modeling. Journal of Cleaner Production, 181:145-154 doi:10.1016/j.jclepro.2018.01.138.

Fuentes, A. B., Canevesi, R. L. S., Gadonneix, P., Mathieu, S., Celzard, A., \& Fierro, V. (2020) Paracetamol removal by Kon-Tiki kiln-derived biochar and activated carbons. Industrial Crops and Products. doi:10.1016/j.indcrop.2020.112740.

Gabelman, A. (2017) Adsorption basics: part 1. Nova York.

García-Mateos, F. J., Ruiz-Rosas, R., Marqués, M. D., Cotoruelo, L. M., Rodrígues-Mirasol, J., \& Cordero, T. (2015) Removal of paracetamol on biomassderived activated carbon: Modeling the fixed bed breakthrough curves using batch adsorption experiments. Chemical Engineering Journal, 279:18-30. doi:10.1016/j.cej.2015.04.144.

Gascó, G., Paz-Ferreiro, J., Álvarez, M. L., \& Méndez, A. S. (2018) Biochars e hydrochars preparados por pirólise e carbonização hidrotérmica de esterco de porco. Waste Manag. doi:10.1016/J.WASMAN.2018.08.015.

Gupta, J., \& Nain, A. K. (2019) Physicochemical study of solute-solute and solute-solvent interactions of homologous series of $\alpha$-amino acids in aqueousisoniazid solutions at temperatures from 293.15 to 318.15 K. J Mol Liq. Journal of Molecular Liquids, 278:262-278. doi:10.1016/j.molliq.2019.01.036.

Gurke, R., Rößler, M., Marx, C., Diamond, S., Schubert, S., Oertel, S., \& Fauler, J. (2015) Occurrence and removal of frequently prescribed pharmaceuticals and corresponding metabolites in wastewater of a sewage treatment plant. Science of the Total Environment. doi:10.1016/j.scitotenv.2015.06.067.

Gwenzi, W., Chaukura, N., Wenga, T., \& Mtisi, M. (2020) Biochars as media for air pollution control systems: Contaminant removal, applications and future research directions environmental science. doi: 10.13140/RG.2.2.33647.87206.

Haro, N. K., Dávila, I. V. J., Nunes, K. G. P., Franco, M. A. E., Marcilio, N. R., \& Féris, L. A. (2021) Kinetic, equilibrium and thermodynamic studies of the adsorption of paracetamol in activated carbon in batch model and fixed-bed column. Applied Water Science. doi:10.1007/s13201-020-01346-5

Jorge, I. R., Tavares, F. P., \& Santos, K. G. (2021) Reuse of sugarcane bagasse as a bioadsorber in the removal of methylene blue in a fixed bed. Brazilian Journal of Science, Technology and Innovation 5:1-15. doi:10.18554/rbcti.v5i1.3346.

Lawal, A. A., Hassan, M. A., Farid, M. A. A., Yasim-Anuar, T. A. T., Samsudin, M. H., Yusoff, M. Z. M., \& Shirai, Y. (2021) Adsorption mechanism and effectiveness of phenol and tannic acid removal by biochar produced from oil palm frond using steam pyrolysis. Environmental Pollution. doi:10.1016/j.envpol.2020.116197.

Lawal, A. A., Hassan, M. A., Farid, M. A. A., Yasim-Anuar, T. A. T., Samsudin, M. H., Yusoff, M. Z. M., \& Shirai, Y. (2021) Adsorption mechanism and efficacy of the removal of phenol and tannic acid by biochar produced from palm fronds using steam pyrolysis. Environment Pollution. doi:10.1016/j.envpol.2020.116197.

Lee, B. X., Kjaerulf, F., Turner, S., Cohen, L., Donnelly, P. D., Muggah, R., Davis, R., Realini, A., Kieselbach, B., MacGregor, L. S., Waller, I., Gordon, R., Moloney-Kitts, M., Lee, G., \& Gilligan, J. (2016) Transforming Our World: Implementing the 2030 Agenda Through Sustainable Development Goal Indicators. J Public Health Policy. doi:10.1057/s41271-016-0002-7.

Lima, D. R., Hosseini-Bandegharaei, A., Thue, P. S., Lima, E. C., Albuquerque, Y. R., Reis, G. ,S., \& Tran, H. N., (2019). Efficient acetaminophen removal from water and hospital effluents treatment by activated carbons derived from Brazil nutshells. Colloids and Surfaces A: Physicochemical and Engineering Aspects 583:123-966. doi: 10.1016/j.colsurfa.2019.123966.

Lima, J. P., Alvarenga, G., Rosa, G., \& Lopes, T. (2018) Obtaining charcoal from timbaúva bark (Enterolobium contortisilquum) and its application in the methylene blue adsorption process. Blucher Chemical Engineering Proceedings. doi:0.5151/chemeng-cobeqic2017-052.

Marcelino, G. R., Carvalho, K. Q., Lima, M. X., Passig, F. H., Belini, A. D. Bernardelli, J. K. B., \& Nagalli, A. (2020) Construction waste as substrate in vertical subsuperficial constructed wetlands treating organic matter, ibuprofenhene, acetaminophen and ethinylestradiol from low-strength synthetic wastewater. Science of The Total Environment. doi:10.1016/j.scitotenv.2020.138771.

Martins, A. F., Villetti, M. A., Mortari, S. R., Pedroso, G. B., Saldanha, L. F., \& Rambo, M. K. (2020) Detoxification of fermentable broth with activated biocarbon resulting from pyrolysis of agro-forestry residues. Water Environment Research. doi:10.1002/wer.1505.

Miranda, S. M. R., Veras, C. A. G., \& Ghesti, G. F. (2020). Charcoal production from waste pequi seeds for heat and power generation. Waste Management. doi:10.1016/j.wasman.2019.12.025

Moino, B. P., Costa, C. S. D., Silva, M. G. C., \& Vieira, M. G. A., (2017) Removal of nickel ions on residue of alginate extraction from Sargassum f ilipendula seaweed in packed bed. Journal of Water Process Engineering, 95:2120-2128. doi:10.1002/cjce.22859. 
Moura, N. F., Chaves, L. J., \& Naves, R. V. (2013) Characterization of pequi fruits (Caryocar brasiliense Camb.) from Brazilian cerrado. Rev. Árvore. doi:10.1590/S0100-67622013000500013.

Nascimento, R. F. D., Lima, A. C. A. D. et al (2020) Adsorption: theoretical aspects and environmental applications. Fortaleza, Brasil.

Nourmoradi, H., Moghadam, K. F., Jafari, A., \& Kamarehie, B. (2018) Removal of acetaminophen and ibuprofen from aqueous solutions by activated carbon derived from Quercus Brantii (Oak) acorn as a low-cost biosorbent. Journal of Environmental Chemical Engineering, 6:6807-6815. doi:10.1016/j.jece.2018.10.047.

Oliveira, F. F., Moura, K. O., Costa, L. S., Vidal, C. B., Loiola, A. R., \& Nascimento, R. F. (2020) Reactive Adsorption of Parabens on Synthesized Micro and Mesoporous Silica from Coal Fly Ash: pH Effect on the Modification Process. ACS Omega. doi:10.1021/acsomega.9b03537.

Olu-Owolabi, B. I., Diagboya, P. N., Mtunzi, F. M., \& Düring, R. A. (2021) Utilizing eco-friendly kaolinite-biochar composite adsorbent for removal of ivermectin in aqueous media. Journal of Environmental Management, 279:111--619. doi:10.1016/j.jenvman.2020.111619.

Ortiz, F. J. G., Rodríguez, M. B., \& Yang, R. T. (2019) Modeling of fixed-bed columns for gas physical adsorption. Chemical Engineering Journal, 378:121985. doi:10.1016/j.cej.2019.121985.

Patra, B. R., Mukherjee, A., Nanda, S. et al (2021) Biochar production, activation and adsorptive applications: a review. Environmental Chemistry Letters. doi:0.1007/s10311-020-01165-9.

Pedroza, M. M., Sousa, J. F., Vieira, G. E. G., \& Bezerra, M. B. D. (2014) Characterization of the products from the pyrolysis of sewage sludge in 1 kg/h rotating cylinder reactor. Journal of Analytical and Applied Pyrolysis, 105:108-115. doi:10.1016/j.jaap.2013.10.009.

Pereira, A. S., Shitsuka, D. M., Parreira, F. J., \& Shitsuka, R. (2018). Metodologia da pesquisa científica.

Pin, C. F., Carvalho, P. E. B., Mesquita, V. R., Lima, D. R., Morais, M. M., Almeida, A. R. F., \& Rodrigues, L. M. (2021) Use of Butiá Bagasse in the Treatment of Effluents for the Removal of Dye. Brazilian Journal of Animal and Environmental Research, 4:1-15. doi: 10.34188/bjaerv4n1-066

Pozo, P. C., Rego, F., Yang, Y., Puy, N., Bartrolí, J., Fàbregas, E., \& Bridgwater, A. V. (2021) Converting coffee silverskin to value-added products by a slow pyrolysis-based biorefinery process. Fuel Processing Technology. doi:10.1016/j.fuproc.2020.106708.

Resplandes, S.P.R. et al (2019) Removal of blue dye from metinel in aqueous solution using pineapple peel and crown. https://propi.ifto.edu.br/ocs/index.php/jice/10jice/paper/viewFile/9792/4396. Accessed April 26, 2021.

Ribas, P. P., Santos, E. O., Costa, C. C., \& Gonzáles, P. L. S. (2021) Estudos sobre remoção de micropoluentes emergentes em efluentes no Brasil: uma revisão sistemática. Revista Brasileira de Meio Ambiente 9:1-11.

Rodrigues, C. C., Lima, E. L., Nóbrega, S. W., \& Santos, W. L. (2019) Removal of caffeine present in aqueous solutions through adsorption on a fixed bed column. In: Engineering Science and technology, $5^{\mathrm{a}}$ Ed. Brasil, pp 388-416

Santos, K. G., Silva, A. L., Toigo, S., Lima, L. J., Oliveira, J., Minaré, M. M., Martins, P. R. G., Dantas, S. C., \& Silvério, B. C. (2021) Online blended approach (PBL) applied to learning separation process in chemical engineering. Research, Society and Development.doi:10.33448 / rsd-v10i1.11408.

Schmal, M., (2014). Chemical reaction engineering: essentials, exercises and examples. New York.

Sellaoui, E. C. L., Lima, G. L., \& Dotto, A. B. L. (2017) Adsorption of amoxicillin and paracetamol on modified activated carbons: equilibrium and positional entropy studies. J. Mol. Liq. doi:10.1016/j.molliq.2017.03.111.

Silva, J. G., Junior, E. J. A., Roeder, J. S., Oliveira, K. B., \& Ferreira, M. P. (2017) Validação de Método Analítico para a Quantificação de Paracetamol em Solução Oral por Espectrofotometria no UV. Revista Virtual de Química, 9:1747-1759 doi:10.21577/1984-6835.20170101.

Thomas, H. C. (1944) Heterogeneous Ion Exchange in a Flowing System. Journal of the American Chemical Society.

Veiga, T. D. L. A., et al (2017) Different plant biomass characterizations for biochar production.

Villaescusa, I. et al. (2011) Mechanism of paracetamol removal by vegetable wastes: The contribution of П-П interactions, hydrogen bonding and hydrophobic effect. Desalination. doi:10.1016/j.desal.2010.11.037.

Yanyan, L. et al (2018). Acetaminophen removal from synthetic wastewater in a fixed bed column adsorption using low-cost coconut shell residues pre-treated with $\mathrm{NaOH}, \mathrm{HNO} 3$, ozone and / or chitosan. Journal of Environmental Management, 226:365-376. doi:10.1016/j.jenvman.2018.08.032. 